\author{
PAWEŁ WAŃCZYK \\ Uniwersytet Papieski Jana Pawła II w Krakowie \\ paw-wan@wp.pl
}

\title{
Wychowawcze wskazówki dla rodziców w Corpus Paulinum
}

Ostatecznym powołaniem człowieka jest wieczne przebywanie z Bogiem. Przepustką pozwalającą osiągnąć ten przyszły nadprzyrodzony stan jest obecne ziemskie życie przeżyte w sposób dobry i święty. Dlatego pojawia się potrzeba nieustannej formacji człowieka. Aczkolwiek mówiąc o kształtowaniu osobowości, charakteru i duchowości, trzeba stwierdzić, że nieocenioną rolę odgrywają tu pierwsze lata tego procesu, gdyż to właśnie powstałe wówczas postawy mają olbrzymi wpływ na dalsze życie i później owocują albo czynionym dobrem i szczęściem, albo prowadzą do upadku i osobistego niespełnienia. Z tego właśnie względu warto przyjrzeć się biblijnym pouczeniom mówiącym o wychowaniu dzieci i nakreślającym, jak powinny być formowane relacje w rodzinie, tak aby wzrastający w niej młody człowiek miał właściwe i zdrowe środowisko do swojego rozwoju. Wszystko to w celu wydobycia wskazań będących pomocą dla rodziców oraz innych osób odpowiedzialnych za to ważkie zadanie, jakim jest chrześcijańskie formowanie młodych ludzi.

Zakres prowadzonych badań egzegetycznych został w niniejszym artykule ograniczony do pism Pawłowych ${ }^{1}$ i Listu do Hebrajczyków.

${ }^{1}$ Autor nie będzie tu wprowadzał rozróżnienia na listy proto- i deuteropawłowe, gdyż kwestia autorstwa listów św. Pawła jest kwestią cały czas badaną i dyskutowaną, 
Treści Starego Testamentu zostały pominięte, gdyż co prawda posiadają niezwykle dużą wartość (dla omawianego tematu szczególnie ważne są księgi mądrościowe), ale z powodów historycznych nie mają one jeszcze znamion nowotestamentowej doskonałości, płynącej z pełni objawienia dokonanego w Jezusie Chrystusie. Natomiast jeśli chodzi o materiał Nowego Testamentu, to został on ograniczony do Corpus Paulinum, ponieważ w nim zawiera się większość praktycznych wskazań dotyczących zagadnienia wychowania.

\section{Pedagogiczne wskazówki w listach św. Pawła}

Jeśli chodzi o treść listów św. Pawła, to najbardziej przydatnymi fragmentami dla omawianego tematu będą tzw. tablice czy też kodeksy domowe z Kol 3, 18-4, 1 i Ef 5, 22-6, 9², które są zbiorami wskazań dla członków rodziny, jak należy postępować. Mówią one o potrzebie podległości żon, dzieci i niewolników względem panów domu, które to pouczenia mogą być niezrozumiałe, a nawet oburzające dla współczesnego odbiorcy. Trzeba tutaj wskazać, iż takie podejście wynika z panującego wówczas powszechnie systemu patriarchalnego, a jego surowość jest niejako przełamywana przez autora tych listów wezwaniami mającymi nakłonić ojców do godnego traktowania tych, którzy są im podporządkowani ${ }^{3}$. I te zachęty do wzajemnego szacunku oraz ich uzasadnienie, że

a jednocześnie nie ma większego znaczenia dla podjętego w artykule tematu.

${ }^{2} \mathrm{O}$ tablicach domowych można jeszcze mówić w 1 P 2, 13-3, 7, z tym że ten fragment nie porusza tematu relacji dzieci i rodziców, a tylko wersety mówiące o tym zagadnieniu zostaną poddane głębszej analizie. W Nowym Testamencie znajdują się jeszcze inne wypowiedzi przypominające charakterem kodeksy domowe, jednakże są one krótsze i nie tworzą takich zbiorów.

${ }^{3}$ Por. A. Standhartinger, The Origin and Intention of the Household Code in the Letter to the Colossians, „Journal for the Study of the New Testament” 23 (2001) nr 79, s. 117130, http://dx.doi.org/10.1177/0142064X0102307910; F. Mickiewicz, Zagadnienia etyczne, [w:] Teologia Nowego Testamentu, t. 3: Listy Pawłowe, Katolickie i List do Hebrajczyków, red. M. Rosik, Wrocław 2008, s. 350n (Bibliotheca Biblica). 
pokojowe relacje domowników podobają się Bogu i są naśladowaniem postępowania Chrystusa, sprawiają, iż przesłanie tych pouczeń jest aktualne także i dzisiaj.

Na początku kodeksów domowych jest mowa o wzajemnej relacji małżonków. Z jednej strony żony mają być poddane mężom, tak jak Kościół jest poddany Chrystusowi, a z drugiej mężowie powinni kochać swoje żony jak własne ciało, a wręcz tak jak Chrystus miłuje Kościół (por. Ef 5, 22-33). Można zatem mówić wręcz o wzajemnym podporządkowaniu i oddaniu obojga małżonków względem siebie (por. Ef 5, 21), a bazująca na takim fundamencie szczera, wzajemna miłość męża i żony jest prawdziwie zdrowym środowiskiem, jakie powinny mieć zapewnione przychodzące na świat ich dzieci ${ }^{4}$. Nic więc dziwnego, iż po omówieniu tematu relacji małżonków następuje ukazanie zasad mających panować między rodzicami i dziećmi. Autor nawołuje: „Dzieci, bądźcie posłuszne rodzicom we wszystkim, bo to jest miłe w Panu" (Kol 3, 20). Na początku warto zauważyć że wezwanie to skierowane jest do dzieci, a zatem widać, że uczestniczyły one w chrześcijańskich celebracjach, na których właśnie odczytywano listy apostolskie ${ }^{5}$. Użyty tu termin $\tau \dot{\kappa} \kappa v a$ („dzieci”) nie pozwala precyzyjnie stwierdzić ich wieku ${ }^{6}$, jednakże kierowanie do nich przesłania świadczy o tym, że były już one na tyle dojrzałe, by zrozumieć jego sens i wagę. Zastosowany wyraz nie sugeruje również płci odbiorców, tak więc można stwierdzić, że „zarówno chłopcy, jak i dziewczęta traktowani są w 3, 20 jako świadome i odpowiedzialne osoby, współkształtujące życie rodzinnego domu i zdające sobie sprawę ze swego powołania do życia w Chrystusie (por. 3, 20b; 1 Kor 7, 14)" ${ }^{\text {7 }}$. Zatem już w samym

${ }^{4}$ Por. H. Langkammer, List do Kolosan. Tłumaczenie, wstęp i komentarz, Lublin 2002, s. 90 (Biblia Lubelska).

${ }^{5}$ Por. J. D. Dunn, The Epistles to the Colossians and to Philemon. A Commentary on the Greek Text, Grand Rapids 1996, s. 250 (The New International Greek Testament Commentary).

${ }^{6}$ Por. M. Barth, H. Blanke, Colossians. A New Translation with Introduction and Commentary, New York-London-Toronto 1994, s. 439 (The Anchor Bible, 34B).

${ }^{7}$ B. Adamczewski, List do Filemona. List do Kolosan. Wstęp, przekład z oryginału, komentarz, Częstochowa 2006, s. 330 (Nowy Komentarz Biblijny Nowy Testament, 12). 
skierowaniu słów do młodszych domowników widać głęboki szacunek dla nich oraz niezmierne docenienie warte naśladowania.

Wezwanie „bądźcie posłuszne” wyrażone czasownikiem ítakoú $\omega$ niesie w sobie ideę słuchania przez osobę podległą komuś, kto jest „nad nią". W tym wypadku „zwierzchnikami” są oczywiście przede wszystkim ojciec i matka, choć drugorzędnie mogą być nimi także inni starsi członkowie rodu (np. dziadkowie), bo na takie szersze tłumaczenie pozwala użyty tu rzeczownik joveú $\varsigma^{8}$. To posłuszeństwo dzieci ma obejmować

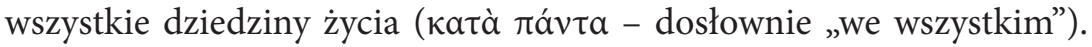
Jednakże trzeba zwrócić uwagę, iż taka szeroka władza rodziców nad swoimi pociechami nie wynika z jakiś autorytarnych zapędów, lecz z ich większej mądrości i bogatszego doświadczenia życiowego, i jest ona im udzielona przy naturalnym założeniu ${ }^{9}$, iż pragną oni prawdziwego dobra dla swojego potomstwa ${ }^{10}$.

Natomiast patrząc od strony dzieci, ich posłuszeństwo powinno być też wyrazem wdzięczności dla rodziców za dar życia oraz okazaną troskę i opiekę ${ }^{11}$. Jednak św. Paweł nie pozostaje tylko na takim ludzkim poziomie argumentacji, lecz wskazuje motywację o charakterze religijnym: „to jest miłe w Panu”, a w paralelnym tekście Ef 6, 1-3 rozbudowuje to uzasadnienie, pisząc: „bo to jest sprawiedliwe. Czcij ojca twego i matkę - jest to pierwsze przykazanie z obietnicą - aby ci było dobrze i abyś był

${ }^{8}$ Por. J. Łach, Kodeks domowy w Liście do Kolosan (Kol 3, 18-4, 1), „Analecta Cracoviensia" 27 (1995), s. 222n.

${ }^{9}$ Takie naturalne pragnienie dobra rodziców dla dzieci jest dość oczywiste i dlatego też zostało użyte w argumentacji przez Jezusa chcącego pokazać dobroć Ojca: „Jeżeli którego z was, ojców, syn poprosi o chleb, czy poda mu kamień? [...] Jeśli więc wy, choć źli jesteście, umiecie dawać dobre dary swoim dzieciom, o ileż bardziej Ojciec z nieba da Ducha Świętego tym, którzy Go prosząa" (Łk 11, 11-13).

${ }^{10}$ Por. J. D. Dunn, The Epistles to the Colossians..., dz. cyt., s. 250. Zatem ten nakaz posłuszeństwa wobec rodziców nie dotyczy sytuacji, w której polecenie ojca czy matki stałoby w opozycji do Prawa Bożego, gdyż wówczas należało by się podporządkować temu drugiemu (por. Dz 5, 29) - por. P. T. O’Brien, Colossians. Philemon, Dallas 1982, s. 225 (Word Biblical Commentary, 44).

${ }^{11}$ Por. F. Mickiewicz, Zagadnienia etyczne..., dz. cyt., s. 351. 
długowieczny na ziemi”. Młodzi domownicy powinni zatem słuchać rodziców, bo właśnie takie zachowanie podoba się Bogu. Jest ono wypełnianiem tego, co przystoi, co właściwe, a przede wszystkim stanowi realizację czwartego przykazania dekalogu. Ten ostatni sposób argumentacji jest o tyle znamienny, iż spośród sześciu przytoczeń przykazania czci ojca i matki w Nowym Testamencie ${ }^{12}$ jest to jedyny przypadek cytowania go wraz z obietnicą ${ }^{13}$. Autor chce zatem zachęcić młodych ludzi do szacunku wobec rodziców poprzez ukazanie im nagrody, która czeka ich już tu na ziemi, a będzie nią ich szczęśliwe i długie życie ${ }^{14}$.

Po wskazaniu dzieciom właściwego zachowania względem ojca i matki św. Paweł przechodzi do pouczeń, jak powinni postępować ci drudzy: „Ojcowie, nie rozdrażniajcie waszych dzieci, aby nie traciły ducha”

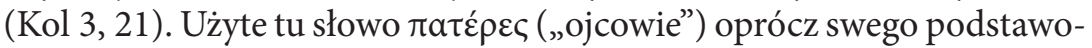
wego znaczenia, gdy tak jak tutaj jest użyte w liczbie mnogiej, może odnosić się do obojga rodziców, na co wskazuje choćby werset Hbr 11, $23^{15}$. Świadczy to o tym, iż myśl autorów Nowego Testamentu wykraczała i przewyższała zarówno starotestamentalną, jak i pogańską mentalność, według której za wychowanie potomstwa, a szczególnie synów, byli odpowiedzialni tylko ojcowie. Natomiast fakt pominięcia terminu rodzice i zastąpienia go słowem „ojcowie” można tłumaczyć tym, że to właśnie mężczyźni są bardziej skłonni do surowego sposobu wychowania swoich dzieci i dlatego właśnie do nich w pierwszym rzędzie jest kierowane to wezwanie ${ }^{16}$.

${ }^{12}$ Oprócz Ef 6, 2-3 czwarte przykazanie cytowane jest jeszcze w Mt 15, 4; 19, 19; Mk 7, 10; 10, 19; Łk 18, 20.

${ }^{13}$ Autor listu, przytaczając tu obietnicę z Wj 20, 12 LXX, świadomie pomija jej fragment dotyczący nagrodzenia darem ziemi obiecanej - Kanaanu. Celem takiego zabiegu jest to, by kierowane przesłanie było bardziej uniwersalne - por. A. Jankowski, Listy więzienne świętego Pawła. Do Filipian - do Kolosan - do Filemona - do Efezjan. Wstęp - przekład z oryginału - komentarz, Poznań 1962, s. 492 (Pismo Święte Nowego Testamentu, 8).

${ }^{14}$ Por. A. T. Lincoln, Ephesians, Dallas 1990, s. 404-406 (Word Biblical Commentary, 42).

${ }^{15}$ Por. M. Barth, H. Blanke, Colossians..., dz. cyt., s. 443.

${ }^{16}$ Por. J. Łach, Kodeks domowy..., dz. cyt., s. 222-224. 
Treść tego pouczenia nawołuje, by nie rozdrażniać dzieci. Trzeba zauważyć, iż sam zastosowany tu grecki czasownik $\varepsilon \rho \theta \hat{\zeta} \zeta \omega$ ma wydźwięk obojętny - „oznacza ogólnie: pobudzanie, podrażnianie, prowokowanie do czegoś: zarówno pozytywnego (np. do rywalizacji - 2 Kor 9, 2), jak i negatywnego (np. do gniewu - Pwt 21, 20; 1 Mch 15, 40)"17. Jednakże w omawianym fragmencie $\dot{\varepsilon} \rho \varepsilon \theta^{\prime} \zeta \omega$ ma znaczenie negatywne i zgodnie z Biblia Tysiąclecia całe wyrażenie może być tłumaczone „nie rozdrażniajcie”. Świadczy o tym zarówno paralelny werset Ef 6, 4, w którym

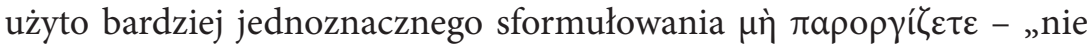
pobudzajcie do gniewu" ${ }^{18}$, jak i znajdujące się w dalszej części omawianego wersetu uzasadnienie takiego upomnienia: „aby nie traciły ducha” $\left(\mathrm{Kol} \mathrm{3,} \mathrm{21b)}{ }^{19}\right.$. Jest tu więc zawarta przestroga przed takim podejściem wobec młodego człowieka, które powodowałoby u niego utratę odwagi i zapału oraz wywoływałoby niepewność lub poirytowanie mogące skutkować późniejszymi problemami związanymi z jego życiem społecznym i religijnym. Zatem rodzice (w szczególności ojcowie) powinni w wychowaniu synów i córek unikać zachowań i słów, które mogą prowadzić do ich rozgoryczenia, przygnębienia, zalęknienia czy też buntu, a kierować się miłością, cierpliwością oraz zrozumieniem, by w ten sposób umożliwić i sprzyjać ich pełnemu rozwojowi ${ }^{20}$.

Tak więc w omawianym tekście wyjątkową i charakterystyczną rzeczą jest skoncentrowanie się na obowiązkach rodziców czy też ojca przy jednoczesnym przemilczeniu kwestii autorytetu rodzicielskiego i potrzeby karnego wychowania - tematów, które przeważnie pojawiały się w starożytnych tekstach pedagogicznych tamtego okresu, a co uderzające,

${ }^{17}$ B. Adamczewski, List do Filemona..., dz. cyt., s. 331.

${ }^{18}$ Por. T. Herrmann, Obowiązki rodziców względem dzieci w Nowym Testamencie, „Ruch Biblijny i Liturgiczny” 14 (1961) nr 1-2, s. 44.

${ }^{19}$ Użyty tu czasownik ả $\theta v \mu \varepsilon ́ \omega$ - „tracić ducha” jest hapax legomenon Nowego Testamentu, natomiast jego znaczenie jako „tracić odwagę, bać się oraz smucić się” ilustruje jego liczne wystąpienia w LXX, m.in. w Pwt 28, 65; 1 Krn 13, 11; Jdt 7, 22; por. P. T. O’Brien, Colossians. Philemon..., dz. cyt., s. 226.

${ }^{20}$ Por. H. Langkammer, List do Kolosan..., dz. cyt., s. 91; B. Adamczewski, List do Filemona..., dz. cyt., s. 331n. 
występują również we wspomnianej paraleli w Ef $6,4^{21}$ : „wychowujcie je [dzieci], stosując karcenie i napominanie Pańskie”. Zatem by dobrze

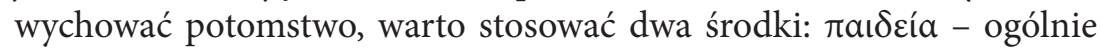

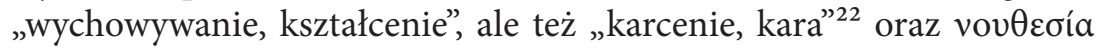
- „pouczenie, napomnienie, przestroga” (etymologicznie „nastawianie rozumu") ${ }^{23}$. Jednak w takim zestawieniu pojęć zastanawia ich nierówny zakres znaczeniowy: $\pi \alpha$ ısía oznacza ogólnie formowanie młodego człowieka, jak i jego uczenie, a nawet karanie (także cielesne), natomiast

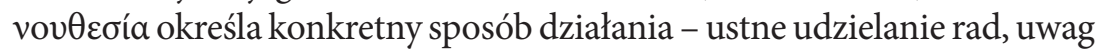
czy upomnień. Ponadto pierwszy z tych dwóch terminów stwarza jeszcze inny kłopot, a mianowicie to, że może być odczytany jako karcenie fizyczne. Zatem można by w omawianym wezwaniu doszukiwać się zachęty do karania cielesnego, ale takie przesłanie kłóci się z omówionym powyżej paralelnym tekstem z Kol 3, 21 oraz całym przesłaniem kodeksów domowych, w których silnie akcentowana jest powinność powściągnięcia surowości przez pana domu. Rozwiązaniem tego problemu może być inne przetłumaczenie spójnika kaí - nie na sposób łączny „i”, lecz wyjaśniająco „to jest” ${ }^{24}$. Wówczas analizowane wskazanie sugerowałoby potrzebę kształcenia dzieci „poprzez wychowanie ( $\dot{\varepsilon} \vee \pi \alpha ı \delta \varepsilon i ́ a)$ ) to jest

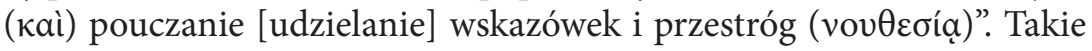
odczytanie tych słów mocno podkreśla wagę rozmów rodziców z dziećmi i pokazuje, że jeśli ojciec z matką chcą mieć wpływ na wychowanie swych pociech, to muszą mieć z nimi dobry kontakt, a ten możliwy jest tylko poprzez poświęcanie im czasu.

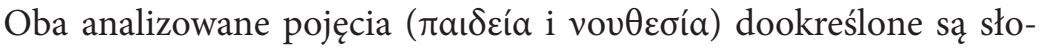
wem kupíou - „Pana”, co wskazuje, że takie formowanie można określić

${ }^{21}$ Por. J. D. Dunn, The Epistles to the Colossians..., dz. cyt., s. 251.

${ }^{22}$ Por. R. Popowski, Wielki słownik grecko-polski Nowego Testamentu. Wydanie z pełna lokalizacja greckich haseł, kluczem polsko-greckim oraz indeksem form czasownikowych, Warszawa 1994, s. 455 (Prymasowska Seria Biblijna, 3).

${ }^{23}$ Por. A. Jankowski, Listy więzienne świętego Pawła..., dz. cyt., s. 493n.

${ }^{24}$ Por. W. J. Larkin, Ephesians. A Handbook on the Greek Text, Waco 2009, s. 148 (Baylor Handbook on the Greek New Testament). 
chrześcijańską pedagogiką - „na sposób i w imieniu Chrystusa” ${ }^{25}$, bo to właśnie do Niego Paweł odnosi tytuł кúpıoৎ - „Pan”. Nie brak także innych interpretacji doprecyzowania kształcenia przy pomocy słowa „Pan”. Spośród nich godną zauważenia jest ta, która mówi, iż chodzi tu o to, by dzieci były nauczane o Jezusie i Jego nauce. Naświetla to prawdę, że same spotkania wspólnoty chrześcijan na celebrację i katechezę nie wystarczą, lecz potrzeba jeszcze religijnej atmosfery $\mathrm{w}$ domu rodzinnym ${ }^{26}$.

Praktyczną realizację tej ostatniej myśli z tablic domowych widać $\mathrm{w}$ Listach do Tymoteusza. Zawierają one fragmenty opisujące okoliczności, w jakich wychowywał się ich adresat i jakie doprowadziły go do wiary - wiary, która „zamieszkała pierwej w jego babce Lois i w jego matce Eunice" (2 Tm 3, 14b). Paweł chwali postawę tych dwóch kobiet, gdyż z racji, iż ojciec Tymoteusza był poganinem, to właśnie one musiały przejąć rolę chrześcijańskiego wychowania syna i wnuka, i wywiązały się z tego obowiązku bardzo dobrze. Widać więc, że nawet wtedy, gdy tylko jedno z rodziców jest uczniem Chrystusa, to jego prawdziwa religijność przyczynia się do właściwego wychowania dziecka. A pomijając specyficzną sytuację tej konkretnej rodziny, można ogólnie stwierdzić, iż prawdziwym źródłem wiary dzieci jest żywa i autentyczna wiara rodziców $^{27}$. Dodać jednak trzeba, że obok przykładu życia, ważną rzeczą jest też uczenie maluchów treści wiary. Pokazują to następujące słowa skierowane przez Apostoła do Tymoteusza: „Ty natomiast trwaj w tym, czego się nauczyłeś i co ci zawierzono, bo wiesz, od kogo się nauczyłeś. Od lat bowiem niemowlęcych znasz Pisma święte, które mogą cię nauczyć mądrości wiodącej ku zbawieniu przez wiarę w Chrystusie Jezusie" (2 Tm 3, 14-15). Obok widocznych w przekładzie Biblii Tysiąclecia myśli, że przekazane treści wiary oraz przesłanie Pisma Świętego czynią człowieka prawdziwie mądrym i umacniając jego wiarę, prowadzą do zbawienia, warto także nadmienić, że wyrażenie „bo wiesz, od kogo się nauczyłeś”

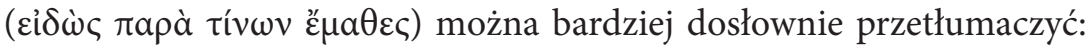
„wiedząc, od których się nauczyłeś”. Taki przekład pozwala zauważyć,

\footnotetext{
${ }^{25}$ A. Jankowski, Listy więzienne świętego Pawła..., dz. cyt., s. 494.

${ }^{26}$ Por. A. T. Lincoln, Ephesians..., dz. cyt., s. 408.

${ }^{27}$ Por. T. Herrmann, Obowiązki rodziców..., dz. cyt., s. 47.
} 
iż na wiarę Tymoteusza miało znaczny wpływ co najmniej kilka osób ${ }^{28}$. Oprócz samego Pawła wśród nich musiały być wspomniane już matka i babka, skoro następny werset mówi: „od lat bowiem niemowlęcych ${ }^{29}$ znasz Pisma święte”. Ponieważ Tymoteusz zna je już w młodym wieku, więc należy przypuszczać, że zapewne to właśnie opiekujące się nim kobiety zadbały o jego edukację biblijną ${ }^{30}$. Zatem chrześcijańscy rodzice, świadomi tego, iż słowo Boże jest właśnie tym, co ma kierować życiem człowieka, stopniowo, z wykorzystaniem odpowiednich form przekazu, już od wczesnego wieku powinni wprowadzać swoje dzieci w poznawanie Pisma Świętego.

W listach Pawłowych można również znaleźć przesłanki regulujące materialną stronę relacji ojca i matki do ich potomstwa. Paweł, pisząc do Koryntian o tym, że pragnie po raz kolejny ich odwiedzić, a jednocześnie nie chce podczas tego pobytu być przez nich utrzymywany, argumentuje to następującą maksymą: „Nie dzieci rodzicom winny gromadzić majętności, lecz rodzice dzieciom” (2 Kor 12, 14). Dla Apostoła naturalne jest to, iż rodzice mają zaspokoić podstawowe potrzeby materialne córek i synów, ale, co więcej, również tak zarządzać majątkiem, by później pomóc im, gdy będą wchodzić w dorosłe, samodzielne życie ${ }^{31}$. Jednakże, jak wskazują inne nowotestamentalne wystąpienia użytego tu czasownika $\theta \eta \sigma a v \rho i \zeta \zeta \omega$ („gromadzić majętności”) oraz pokrewnego mu rzeczownika

${ }^{28}$ Por. R. F. Collins, 1 \& 2 Timothy and Titus. A Commentary, Louisville-London 2002, s. 262 (The New Testament Library).

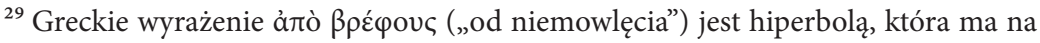
celu wskazanie, iż edukacja biblijna Tymoteusza rozpoczęła się w dość wczesnym wieku. Zatem to wyrażenie można też tłumaczyć jako „od lat najwcześniejszych” - por. R. Popowski, M. Wojciechowski, Grecko-polski Nowy Testament. Wydanie interlinearne z kluczem gramatycznym, z kodami Stronga i Popowskiego oraz pełna transliteracja greckiego tekstu, Warszawa 2014, s. 1146 (Prymasowska Seria Biblijna, 40).

${ }^{30}$ Por. J. Szlaga, Społeczne i teologiczne aspekty biblijnego spojrzenia na dziecko, ,Zeszyty Naukowe Katolickiego Uniwersytetu Lubelskiego" 23 (1980) nr 3, s. 56.

${ }^{31}$ Por. C. S. Keener, Komentarz historyczno-kulturowy do Nowego Testamentu, Warszawa 2000, s. 396 (Prymasowska Seria Biblijna, 16). 


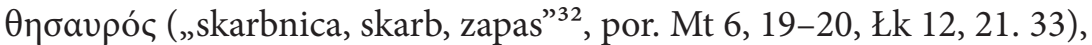
można tu widzieć nie tylko zabieganie o bogactwa i dobra doczesne, ale także wartości niematerialne, jak np. okazane dzieciom poświęcenie i miłość czy też ich duchowe wsparcie oraz modlitwa za nie.

Stwierdzenie „nie dzieci rodzicom winny gromadzić majętności, lecz rodzice dzieciom" pokazuje pewną naturalną prawidłowość występującą w społeczeństwie, że zazwyczaj ojciec z matką pomagają swemu potomstwu. Nie można jednak w tym stwierdzeniu widzieć zasady zwalniającej dzieci z pomocy rodzicom, zwłaszcza w sytuacji, gdy ci jej potrzebują ${ }^{33}$. Potwierdzeniem tego jest Pawłowe pouczenie skierowane do Tymoteusza, biskupa wspólnoty, która miała na utrzymaniu wiele wdów niemających środków do życia. Wśród różnych wskazań Apostoł pisze: „Jeśli zaś jaka wdowa ma dzieci albo wnuki, niechże się one uczą najpierw pieczołowitości względem własnej rodziny i odpłacania się rodzicom wdzięcznością! Jest to bowiem rzeczą miłą w oczach Bożych" $(1 \mathrm{Tm} 5,4)^{34}$. Dzieci już od małego powinny być formowane w duchu służby, aby umiały zauważać potrzeby innych i stosownie do zaistniałej konieczności troszczyć się i opiekować innymi - w późniejszej perspektywie też swoimi starszymi, zniedołężniałymi rodzicami. I właśnie o tej sytuacji mówiła przytoczona przed chwilą nauka św. Pawła. Na koniec warto zauważyć, że jest to fragment odnoszący się do kwestii kształtowania osób już dorosłych ${ }^{35}$. Zatem wychowanie młodych ludzi nie kończy się w momencie osiągnięcia przez nich dojrzałości, lecz powinno się też odbywać w ich dorosłym życiu, tyle że wówczas już bardziej poprzez radę, zachętę i perswazję, z poszanowaniem ich wolności ${ }^{36}$.

${ }^{32}$ Por. R. Popowski, Wielki słownik grecko-polski..., dz. cyt., s. $281 \mathrm{n}$.

${ }^{33}$ Por. R. P. Martin, 2 Corinthians, Dallas 1986, s. 441n (Word Biblical Commentary, 40).

${ }^{34}$ Por. H. Langkammer, Listy pasterskie. Pierwszy list do Tymoteusza. Drugi list do Tymoteusza. List do Tytusa, Lublin 2006, s. 60n (Biblia Lubelska). W Kościele pierwotnym poświęcone Bogu wdowy tworzyły coś w rodzaju odrębnego stanu.

${ }^{35}$ Por. C. S. Keener, Komentarz historyczno-kulturowy..., dz. cyt., s. 476.

${ }^{36}$ Innym tekstem Nowego Testamentu mówiącym o pouczaniu osób dorosłych jest następujące wezwanie dotyczące starszych kobiet: „Niech pouczają młode kobiety, jak mają kochać mężów, dzieci, jak mają być rozumne, czyste, gospodarne, dobre, poddane 


\section{Pedagogiczne wskazówki w Liście do Hebrajczyków}

W drugiej części niniejszego artykułu warto przyjrzeć się, co na temat wychowania mówi List do Hebrajczyków. Pismo to w przeważającej mierze porusza zagadnienia z zakresu chrystologii ${ }^{37}$, jednakże w końcowej części parenetycznej występuje perykopa Hbr 12, 4-11, będąca najdłuższym fragmentem Nowego Testamentu podejmującym temat wychowania, a dokładniej mówiąc, kwestię Bożej pedagogii wyjaśnionej poprzez porównanie jej do ludzkich metod wychowawczych.

Hagiograf, będąc świadomym różnego rodzaju trudności (m.in. wrogość otoczenia, niebezpieczeństwo prześladowań) oraz widząc spowodowane nimi osłabienie wiary adresatów tego listu, ukazuje te przeciwności jako Bożą pedagogię - działanie, które ma na celu tak ukształtować ich myślenie i zachowanie, by byli wiernymi i posłusznymi dziećmi Boga ${ }^{38}$. Pouczenie to jednak rozpoczyna od sformułowania zarzutu opartego na starotestamentalnym cytacie z Prz 3, 11-12: „zapomnieliście o upomnieniu, z jakim się zwraca do was, jako do synów: Synu mój, nie lekceważ karania Pana, nie upadaj na duchu, gdy On cię doświadcza. Bo kogo miłuje Pan, tego karze, chłoszcze zaś każdego, którego za syna przyjmuje”

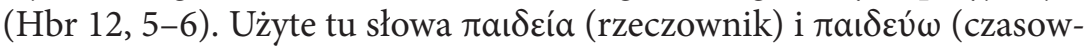
nik) oznaczają „wychowanie, uczenie”, ale też „karanie fizyczne”, które w świecie starożytnym było zwykłą, powszechnie stosowaną metodą wychowawczą. I właśnie w takim znaczeniu termin ten był często stosowany w żydowskiej literaturze mądrościowej na określenie surowego, ale mądrego i kształcącego podejścia Boga do człowieka ${ }^{39}$.

swym mężom - aby nie bluźniono słowu Bożemu” (Tt 2, 4). Wyjaśnienie podległości żon względem mężów znajduje się we wcześniejszym fragmencie artykułu.

${ }^{37}$ Por. A. Tronina, Chrystologia Listu do Hebrajczyków, „Częstochowskie Studia Teologiczne" 25 (1997), s. 23.

${ }^{38}$ Por. R. Brown, The Message of Hebrews. Christ above All, Leicester 1982, s. 231.

39 Takie starotestamentalne użycie terminu $\pi a$ ı́ía przyczyniło się do tego, że Biblia Tysiąclecia częściej tłumaczy go jako „karanie” i „karcenie” niż jako „wychowanie” - por. 
Dla współczesnego człowieka pewną trudność może stanowić przesłanie przytoczonego starotestamentalnego fragmentu, z którego wynika, że skutkiem miłości Boga jest karanie, a wynikiem uznania za syna jest udzielana przez Niego chłosta, przy czym oba z tych sposobów dyscyplinowania obrazują nieprzyjemności i trudności, które spotykają człowieka. Dlatego, aby wyjaśnić tego rodzaju pouczenia, warto przytoczyć kolejne wersety omawianego tekstu: „Bóg obchodzi się z wami jak z dziećmi. Jakiż to bowiem syn, którego by ojciec nie karcił? Jeśli jesteście bez karania, którego uczestnikami stali się wszyscy, nie jesteście synami, ale dziećmi nieprawymi” (Hbr 12, 7b-8). Zatem występuje tu argument wynikający z obserwacji ówczesnego życia społecznego, który wskazuje, że karceniu nie podlegały tylko „dzieci nieprawe”. Zastosowany tu termin vó $\theta$ o oznacza „dzieci nieślubne, poczęte w wyniku grzechu cudzołóstwa”, do których właśnie $\mathrm{z}$ racji ich niechlubnego pochodzenia ojcowie przeważnie się nie przyznawali, nie interesowali się nimi, a w związku z tym nie okazywali żadnej troski o ich wychowanie ${ }^{40}$. Natomiast inaczej sprawy miały się z synami poczętymi w małżeństwach - ci podlegali formacji (która dokonywała się także przez karcenie), tak by w przyszłości zostać mądrymi, dobrymi i szanowanymi obywatelami, a jednocześnie też być godną pochwały wizytówką swoich rodziców ${ }^{41}$. Zatem karcenie i chłosta dokonywana przez kochającego Ojca - Boga są obrazem tego, iż Bogu nie są obojętne Jego dzieci, czyli wierzący w Niego. Nie porzuca ich, lecz formuje je dla ich dobra i przyszłego szczęścia ${ }^{42}$. W tym duchu można też powiedzieć, że aby wychowanie dzieci przez ich ziemskich opiekunów było faktycznie skuteczne, potrzebna jest $\pi \alpha$ ı $\delta$ cía rozumiana niekoniecznie jako karcenie cielesne, ale po pierwsze jako stawianie wymagań

P. Wańczyk, Wpatrzeni w Jezusa. Życie chrześcijan w świetle Listu do Hebrajczyków, Kraków 2015, s. 34n.

${ }^{40}$ Por. R. Bogacz, Misja Chrystusa w świetle hapax legomenów, Kraków 2006, s. 559n (List do Hebrajczyków, 2).

${ }^{41}$ Por. A. Paciorek, List do Hebrajczyków. Tłumaczenie wstęp i komentarz, Lublin 1998, s. 146 (Biblia Lubelska).

${ }^{42}$ Por. R. Bogacz, Dzieło zbawienia w ludzkiej Krwi Jezusa według Listu do Hebrajczyków, Kraków 2007, s. 198 (List do Hebrajczyków, 3). 
i po drugie jako ganienie czy dawanie kar (niefizycznych) w sytuacji, gdy dziecko postępuje źle, a zwykłe upomnienia nie skutkują ${ }^{43}$.

Potwierdzeniem takich wniosków stają się następne słowa autora Listu do Hebrajczyków: „Zresztą, jeśliśmy cenili i szanowali ojców naszych według ciała, mimo że nas karcili, czyż nie bardziej winniśmy posłuszeństwo Ojcu dusz, a żyć będziemy?" (Hbr 12, 9). Hagiograf, chcąc podkreślić zasadność przyjęcia i znoszenia trudności, które Bóg zsyła na człowieka, odwołuje się do doświadczenia adresatów. Zakłada, że praktycznie każdy dorosły człowiek mógłby sobie przypomnieć jakąś sytuację, w której surowość okazana przez rodziców była dla niego jako dziecka bardzo przykra, ale ostatecznie przyniosła niespodziewane pożyteczne skutki ${ }^{44}$. Co więcej, zdarzenie to, jak się często okazuje po latach, nie tylko nie doprowadziło do podważenia autorytetu ojca czy matki, ale nawet zaowocowało wzrostem szacunku dla nich. Stąd płynie też nauka dla rodziców, iż w wychowaniu dzieci mogą pojawić się momenty, gdy bardziej czy mniej świadomie będą one postępować niewłaściwie, a wówczas dla ich dobra i prawdziwego szczęścia szczerze kochający opiekunowie będą musieli być wobec nich nieprzyjemni i stanowczy. Niezmiernie ważną rzeczą jest jednak rozeznanie, kiedy faktycznie taka postawa surowości jest potrzebna.

Ten właściwy osąd oraz związany z nim dobór środków wychowawczych nie jest czymś łatwym, na co wskazuje kolejny werset analizowanego fragmentu: „Tamci [ojcowie] karcili nas według swej woli na czas znikomych dni. Ten [Bóg] zaś czyni to dla naszego dobra, aby nas uczynić uczestnikami swojej świętości" (Hbr 12, 10). Bóg w swojej wszechwiedzy i wszechmocy wychowuje ludzi poprzez doświadczenia, które niezawodnie prowadzą do ich najwyższego dobra i pożytku, jakim jest świętość. I ten cel powinien również przyświecać chrześcijańskim małżonkom w formowaniu potomstwa. Jak podaje tekst, doczesne wy-

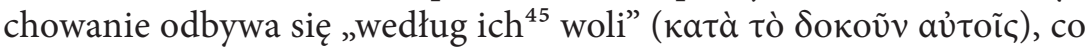

${ }^{43}$ Por. T. Herrmann, Obowiązki rodziców..., dz. cyt., s. 46.

${ }^{44}$ Por. W. L. Lane, Hebrews 9-13, Dallas 1991, s. 423 (Word Biblical Commentary, 47B).

${ }^{45}$ Występujący w tekście greckim zaimek, odnosi się do słowa ratépaৎ („ojców”; por. Hbr 12, 9), z tym że, jak już powiedziano w pierwszej części artykułu, występująca 
należałoby tłumaczyć bardziej dosłownie: „jak im się wydawało [dobrym]”, „według ich uznania” 46 . Jest tu zatem możliwość popełnienia błędów wynikających choćby z fałszywej oceny rzeczywistości, chęci panowania, egoizmu człowieka czy też innych skutków skażenia grzechem pierworodnym. Jednakże mimo tej ludzkiej niedoskonałości rodzice powinni dążyć do tego, by umieć słusznie rozsądzić, co w wychowaniu ich pociech będzie dla nich budujące, a do takiej zdolności można starać się dojść poprzez życie w łasce, ale też przez własną formację duchową i intelektualną.

Dodać trzeba, że te kształtujące zabiegi ojca i matki mają miejsce dosłownie „na nieliczne dni” ( czas znikomych dni”). Wyrażenie to, jak mówią jedni komentatorzy, sugeruje, iż starania wychowawców wpływają tylko na doczesne życie lub, jak wskazują inni, że oddziałują jedynie w trakcie formowania młodego człowieka w domu rodzinnym, a więc do momentu osiągnięcia dorosłości. Natomiast pedagogia Boga trwa przez całe życie człowieka, a jej konsekwencje rozciągają się również na przyszłe niebiańskie bytowanie. Naświetla to zatem pewną względność ludzkiego wychowania i uświadamia ojcu i matce, że tu na ziemi są oni tylko zastępcami Boga ${ }^{47}$.

Na koniec porównywania pedagogii ludzkiej i Bożej autor listu porusza kwestię odczuć tych osób, które podlegały surowemu wychowaniu: „Wszelkie karcenie na razie nie wydaje się radosne, ale smutne, potem jednak przynosi tym, którzy go doświadczyli, błogi plon sprawiedliwości" (Hbr 12, 11). Jest tu zawarta oczywista myśl, że karanie jest przykre dla tych, którzy mu podlegają, ale warto również dodać, iż jego konieczność dla kochających rodziców też nie stanowi rzeczy prostej i przyjemnej ${ }^{48}$. Jednakże trzeba na to patrzyć w szerszej perspektywie, a jest nią nagroda, która w Biblii Tysiaclecia została zilustrowana jako „błogi plon

tu liczba mnoga terminu $\pi \alpha \tau$ ṕ może odnosić się do obojga rodziców.

${ }^{46}$ P. Ellingworth, The Epistle to the Hebrews. A Commentary on the Greek Text, Grand Rapids 1993, s. 655 (The New International Greek Testament Commentary).

${ }^{47}$ Por. S. Łach, List do Hebrajczyków. Wstęp - przekład z oryginału, komentarz - ekskursy, Poznań 1959, s. 275 (Pismo Święte Nowego Testamentu, 10).

${ }^{48}$ Por. A. C. Mitchell, Hebrews, Collegeville 2007, s. 273 (Sacra Pagina Series, 13). 


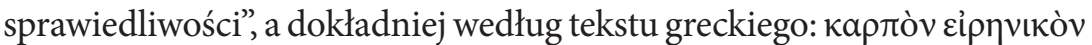

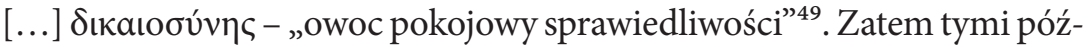
niejszymi pozytywnymi skutkami pedagogicznego formowania są pokój duszy i serca oraz sprawiedliwość czy też prawośćc ${ }^{50}$, a przede wszystkim osiągnięcie najważniejszego celu, jakim jest życie wieczne, bo właśnie je w Biblii oznacza wyrażenie „plon sprawiedliwości”"

Podsumowując więc omawianą perykopę z Listu do Hebrajczyków, należy stwierdzić, iż wychowanie jest długim, ale i przejściowym procesem, podczas którego dzieci muszą doświadczyć zarówno przyjemnych, jak i niezrozumiałych wówczas dla nich, przykrych działań rodziców. Aczkolwiek te ostatnie powinny mieć miejsce tylko wówczas, gdy ich celem jest uczynienie z wychowanków ludzi prawych i posłusznych Bogu oraz doprowadzenie ich do prawdziwego szczęścia i pokoju - ostatecznie zaś do ich zbawienia. Tymi zasadami kieruje się pedagogia Boga względem swoich dzieci - ludzi, i powinna być ona wzorem dla ojców i matek $\mathrm{w}$ formowaniu ich pociech ${ }^{52}$.

\section{Podsumowanie}

Wskazania dotyczące wychowania, które znajdują się w Corpus Paulinum, nie są zbyt liczne, co pozwala stwierdzić, iż omawiany temat nie jest jednym z najważniejszych motywów biblijnych. Nie umniejsza to jednak wagi pouczeń przeanalizowanych w niniejszym artykule. Spośród nich najbardziej wartościowe treści niosą tablice domowe z Listu do Kolosan i Listu do Efezjan. Wynika z nich, jak ważną kwestią są właściwe relacje panujące między członkami rodziny. Rodzice

${ }^{49}$ Por. R. Popowski, M. Wojciechowski, Grecko-polski Nowy Testament..., dz. cyt., s. 1211.

${ }^{50}$ Por. E. McKnight, Ch. Church, Hebrews - James, Georgia 2004, s. 293 (The Smyth \& Helwys Bible Commentary, 28).

${ }^{51}$ Por. K. Romaniuk, A. Jankowski, L. Stachowiak, Komentarz praktyczny do Nowego Testamentu, t. 2, Poznań-Kraków 1999, s. 471.

52 Por. A. Paciorek, List do Hebrajczyków..., dz. cyt., s. 147. 
powinni wykazywać względem dzieci zainteresowanie i poświęcać im czas, podchodzić do nich z szacunkiem i zrozumieniem. Natomiast synowie i córki mają okazywać ojcu i matce posłuszeństwo płynące z wdzięczności rodzicom za dar życia i wychowania, ale przede wszystkim z tego względu, że takie zachowanie podoba się Bogu. Wychowanie $\mathrm{w}$ wierze i prawdziwej religijności ma bowiem kluczową rolę $\mathrm{w}$ formowaniu człowieka do świętości. Olbrzymie znaczenie odgrywa przykład głębokiego życia religijnego ojca i matki, jak też uczenie dzieci treści wiary i wczesne zapoznawanie ich z Biblią. Istotne jest również zaspokajanie materialnych potrzeb młodych ludzi, przy czym musi iść ono w parze $\mathrm{z}$ uwrażliwianiem ich na konieczność pomocy innym. Jednak obok tych pozytywnych metod wychowawczych, w sytuacjach, gdy syn lub córka postępuje źle, dla wskazania, że obrana przez nich droga postępowania jest błędna, konieczna jest bardziej zdecydowana i surowa reakcja opiekunów.

Powyższe pouczenia wyszły spod pióra Pawła lub osób pozostających pod wpływem jego myśli. Wskazują one drogę uświęcenia zarówno dla rodziców, jaki dzieci, w przypadku których odbyta w młodości formacja będzie procentować w ich dorosłym życiu. Motywacją dla wypełniania tych wskazań jest wiara w Boga, która dla chrześcijan jest najważniejszym punktem odniesienia. Zatem wcielanie tych nauk w życie jest jednocześnie realizacją pięknego wezwania Apostoła Pawła: „cokolwiek czynicie, wszystko na chwałę Bożą czyńcie” (1 Kor 10, 31).

\section{Abstrakt}

Pismo Święte koncentruje się przede wszystkim na sprawach duchowych, ale podejmuje też kwestie dotyczące funkcjonowania w codziennym życiu. Do takiej kategorii można zaliczyć wychowywanie dzieci. Chociaż proces ten przynależy do codzienności, to jednak ma nieocenione znaczenie dla przyszłego - doczesnego i nadprzyrodzonego - życia młodego człowieka. Prawda ta stała się dla autora impulsem do podjęcia badań egzegetycznych dotyczących wychowawczych wskazówek, które znajdują się w listach Pawłowych i w Liście do Hebrajczyków. Analiza wybranych tekstów uwypukliła, jak ważną rzeczą jest dbanie o właściwe relacje w rodzinie, na które składa się: troska, szacunek, 
wzajemne zrozumienie, a także posłuszeństwo dzieci względem rodziców. Istotne jest nie tylko zaspokojenie potrzeb materialnych synów i córek, ale też uwrażliwienie ich na pomoc, której powinni udzielać innym ludziom. Natomiast gdy dzieci postępują źle, konieczna jest zdecydowana reakcja opiekunów, mająca na celu uświadomienie im niewłaściwego postępowania. Wszystkie te pouczenia znajdują swoją motywację w wierze w Boga, która dla chrześcijan stanowi najważniejszy punkt odniesienia dla całego ich życia. Nic więc dziwnego, że w listach św. Pawła można znaleźć również fragmenty doceniające wczesną edukację religijną i biblijną.

\section{Słowa kluczowe}

Wychowanie; pedagogia; formacja; dzieci; młodzi; rodzice; ojciec; matka; rodzina; relacje rodzinne

\section{Abstract}

\section{Pedagogical Instruction for Parents in Corpus Paulinum}

The Bible first and foremost focuses on spiritual issues, but also deals with matters related to everyday life. The upbringing of children belongs to the latter category. Despite the fact that it is a mundane activity, it has great significance, both worldly and supernatural, for the future life of a young person. This truth has become a stimulus for the author to undertake exegetical research concerning the pedagogical directions that are contained in the Pauline epistles, as well as in the Letter to the Hebrews. The analysis of selected passages emphasizes how important it is to take care of proper family relationships that are based on concern, respect, mutual understanding, and children's obedience to their parents. It is vital to secure the material needs of sons and daughters, but also to make them empathetic and to encourage them to help people in need. What is more, when children behave inappropriately, parents should be strict and react immediately in order to make them aware of their wrong behavior. All of these suggestions stem from the faith in God, which for Christians should to be the main point of reference in their lives. It is only natural then that in St. Paul's letters we can find verses appreciating the importance of early religious and Biblical education. 


\section{Keywords}

Upbringing; pedagogy; formation children; youth; parents; father; mother; family; family relations

\section{References}

Adamczewski B., List do Filemona. List do Kolosan. Wstęp, przekład z oryginału, komentarz, Częstochowa 2006 (Nowy Komentarz Biblijny Nowy Testament, 12).

Barth M., Blanke H., Colossians. A New Translation with Introduction and Commentary, New York-London-Toronto 1994 (The Anchor Bible, 34B).

Bogacz R., Dzieło zbawienia w ludzkiej Krwi Jezusa według Listu do Hebrajczyków, Kraków 2007 (List do Hebrajczyków, 3).

Bogacz R., Misja Chrystusa w świetle hapax legomenów, Kraków 2006 (List do Hebrajczyków, 2).

Brown R., The Message of Hebrews. Christ above All, Leicester 1982.

Collins R. F., 1 \& 2 Timothy and Titus. A Commentary, Louisville-London 2002 (The New Testament Library).

Dunn J. D., The Epistles to the Colossians and to Philemon. A Commentary on the Greek Text, Grand Rapids 1996 (The New International Greek Testament Commentary). Ellingworth P., The Epistle to the Hebrews. A Commentary on the Greek Text, Grand Rapids 1993 (The New International Greek Testament Commentary).

Herrmann T., Obowiązki rodziców względem dzieci w Nowym Testamencie, „Ruch Biblijny i Liturgiczny” 14 (1961) nr 1-2, s. 43-52.

Jankowski A., Listy więzienne świętego Pawła. Do Filipian - do Kolosan - do Filemona - do Efezjan. Wstęp - przekład z oryginału - komentarz, Poznań 1962 (Pismo Święte Nowego Testamentu, 8).

Keener C. S., Komentarz historyczno-kulturowy do Nowego Testamentu, Warszawa 2000 (Prymasowska Seria Biblijna, 16).

Lane W. L., Hebrews 9-13, Dallas 1991 (Word Biblical Commentary, 47B).

Langkammer H., List do Kolosan. Tłumaczenie, wstęp i komentarz, Lublin 2002 (Biblia Lubelska).

Langkammer H., Listy pasterskie. Pierwszy list do Tymoteusza. Drugi list do Tymoteusza. List do Tytusa, Lublin 2006 (Biblia Lubelska). 
Larkin W. J., Ephesians. A Handbook on the Greek Text, Waco 2009 (Baylor Handbook on the Greek New Testament).

Lincoln A. T., Ephesians, Dallas 1990 (Word Biblical Commentary, 42).

Łach J., Kodeks domowy w Liście do Kolosan (Kol 3, 18-4, 1), „Analecta Cracoviensia” 27 (1995), s. 219-231.

Łach S., List do Hebrajczyków. Wstęp - przekład z oryginału, komentarz-ekskursy, Poznań 1959 (Pismo Święte Nowego Testamentu, 10).

Martin R. P., 2 Corinthians, Dallas 1986 (Word Biblical Commentary, 40).

McKnight E., Church Ch., Hebrews - James, Georgia 2004 (The Smyth \& Helwys Bible Commentary, 28).

Mickiewicz F., Zagadnienia etyczne, [w:] Teologia Nowego Testamentu, t. 3. Listy Pawłowe, Katolickie i List do Hebrajczyków, red. Rosik M., Wrocław 2008, s. 307373 (Bibliotheca Biblica).

Mitchell A. C., Hebrews, Collegeville 2007 (Sacra Pagina Series, 13).

O’Brien P. T., Colossians. Philemon, Dallas 1982 (Word Biblical Commentary, 44).

Paciorek A., List do Hebrajczyków. Tłumaczenie wstęp i komentarz, Lublin 1998 (Biblia Lubelska).

Popowski R., Wielki słownik grecko-polski Nowego Testamentu. Wydanie z petna lokalizacja greckich haset, kluczem polsko-greckim oraz indeksem form czasownikowych, Warszawa 1994 (Prymasowska Seria Biblijna, 3).

Popowski R., Wojciechowski M., Grecko-polski Nowy Testament. Wydanie interlinearne z kluczem gramatycznym, z kodami Stronga i Popowskiego oraz pełna transliteracja greckiego tekstu, Warszawa 2014 (Prymasowska Seria Biblijna, 40).

Romaniuk K., Jankowski A., Stachowiak L., Komentarz praktyczny do Nowego Testamentu, t. 1-2, Poznań-Kraków 1999.

Standhartinger A., The origin and Intention of the Household Code in the Letter to the Colossians, „Journal for the Study of the New Testament” 23 (2001) nr 79, s. 117130, http://dx.doi.org/10.1177/0142064X0102307910.

Szlaga J., Społeczne i teologiczne aspekty biblijnego spojrzenia na dziecko, „Zeszyty Naukowe Katolickiego Uniwersytetu Lubelskiego” 23 (1980) nr 3, s. 51-61.

Tronina A., Chrystologia Listu do Hebrajczyków, „Częstochowskie Studia Teologiczne” 25 (1997), s. 23-29.

Wańczyk P., Wpatrzeni w Jezusa. Życie chrześcijan w świetle Listu do Hebrajczyków, Kraków 2015. 
